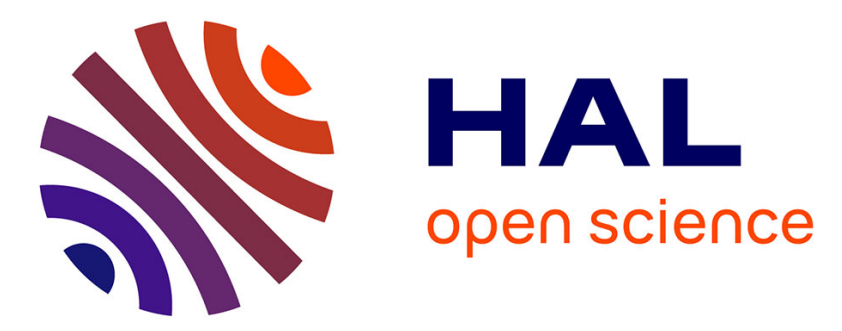

\title{
When endemic coral-reef fish species serve as models: endemic mimicry patterns in the Marquesas Islands
}

\author{
Erwan Delrieu-Trottin, S. Planes, J. T. Williams
}

\section{To cite this version:}

Erwan Delrieu-Trottin, S. Planes, J. T. Williams. When endemic coral-reef fish species serve as models: endemic mimicry patterns in the Marquesas Islands. Journal of Fish Biology, 2016, 10.1111/jfb.13050 . hal-01338324

\section{HAL Id: hal-01338324 \\ https://hal.sorbonne-universite.fr/hal-01338324}

Submitted on 28 Jun 2016

HAL is a multi-disciplinary open access archive for the deposit and dissemination of scientific research documents, whether they are published or not. The documents may come from teaching and research institutions in France or abroad, or from public or private research centers.
L'archive ouverte pluridisciplinaire HAL, est destinée au dépôt et à la diffusion de documents scientifiques de niveau recherche, publiés ou non, émanant des établissements d'enseignement et de recherche français ou étrangers, des laboratoires publics ou privés. 


\title{
When endemic coral-reef fish species serve as models: endemic mimicry patterns in the Marquesas Islands
}

\author{
E. DELRIEU-TROTTIN ${ }^{1,2,3, *}$ S. PLANES ${ }^{1}$, J. T. WILLIAMS ${ }^{4}$ \\ ${ }^{1}$ Laboratoire d Excellence CORAIL, EPHE, PSL Research University, UPVD, CNRS, \\ USR 3278 CRIOBE, Universite de Perpignan, 52 Av. Paul Alduy, F-66860 Perpignan, \\ France, \\ ${ }^{2}$ UMR 7205 ISYEB MNHN, CNRS, UPMC, EPHE; Ecole Pratique des Hautes Etudes, \\ Sorbonne Universites, 57 rue Cuvier, CP39; F-75005, Paris, France, \\ ${ }^{3}$ Instituto de Ciencias Ambientales y Evolutivas, Universidad Austral de Chile, Valdivia, \\ Chile \\ ${ }^{4}$ Division of Fishes, Department of Vertebrate Zoology, National Museum of Natural \\ History, 4210 Silver Hill Road, Suitland, MD, 20746, USA,
}

*To whom correspondence should be addressed: erwan.delrieu.trottin@gmail.com

\begin{abstract}
This article documents several cases of widespread species, which usually mimic other widespread species throughout the Indo-Pacific, using endemic Marquesan species as a model and displaying endemic mimicry patterns. This discovery adds a new line of evidence to the uniqueness of the Marquesas Islands, which not only host a high number of endemic reef-fish species, but also endemic mimicry patterns.
\end{abstract}

Key words: endemism ; Chromis fatuhivae; Coris hewetti; Stethojulis marquesensis; Pseudanthias regalis

Extending over $500 \mathrm{~km}$ between $7^{\circ} 50^{\prime} \mathrm{S}$ and $10^{\circ} 35^{\prime} \mathrm{S}$ latitude and $138^{\circ} 25^{\prime} \mathrm{W}$ and $140^{\circ} 50^{\prime} \mathrm{W}$ longitude, the Marquesas Islands are the northeasternmost archipelago of French Polynesia. Isolated by distance and oceanographic features, they also possess unique environmental conditions (Chevalier, 1978; Randall, 2001), all contributing to yield a unique reef fish fauna. The Marquesas Islands are remarkable for hosting a high number of species unique to that locality (endemic species). They rank third in terms 
of percentage of endemism in the Pacific (Randall \& Earle 2000, Delrieu-Trottin et al., 2015), although only a relatively small portion of the islands have been explored due to the logistical difficulty of assessing the biodiversity in this remote area. An expedition was conducted in November 2011 (Pakaihi i te Moana Expedition) to study the reef fish fauna of every high island and to make the only collections known from Banc Clark and Motu One (submerged atolls) in the Marquesan archipelago. Many additional endemic species (Delrieu-Trottin et al., 2015) were found, and several endemic-based mimicry associations were discovered. This study also discovered several different widespread species, which usually mimic other widespread species throughout the Indo-Pacific, that were using endemic Marquesan species as a model and displaying endemic mimicry patterns.

One particular photograph taken during the expedition led to this discovery [Fig. 1(a)]. The photo depicts the underwater landscape of Banc Clark, a remote submerged atoll at the northernmost point of the Marquesas archipelago that was explored for the first time by the scientific expedition. The photograph shows Chromis fatuhivae Randall 2001, a rare, endemic and iconic species from the Marquesas Islands, living far away from its previously known geographic distribution [Fig. 1 (a), (b), (c)]. This species was named for its type locality Fatu-Hiva, the southernmost island of the Marquesas where it was thought to be restricted (Randall, 2001; Randall, 2005a). In addition to the expanded range, the underwater photograph reveals, more interestingly, a previously unknown mimetic association linked to the endemic Chromis. Hidden among the $C$. fatuhivae, a juvenile Lutjanus bohar (Forsskal 1775) can be seen mimicking the endemic damselfishes [Fig. 1 (a), (b), indicated by the arrow]. Lutjanus bohar is a species whose juveniles extensively use mimicry to approach its prey and hunt more efficiently [aggressive mimicry (Wickler, 1965)], but also to benefit from the defensive strategy of schooling (social mimicry, sensu Randall 2005b). This species is known to mimic and school with several harmless damselfish species of the genus Chromis throughout its Indo-Pacific geographic distribution: Chromis ternatensis (Bleeker 1856) in Indonesia; C. margaritifer Fowler 1946 in Fiji; C. iomelas Jordan \& Seale 1906 in the Tuamotu Archipelago (French Polynesia); and $C$. flavomaculata Kamohara 1960, C. weberi Fowler \& Bean 1928, C. lepidolepis Bleeker 1877, and C. notata (Temminck \& Schlegel 1843) in Japan (Russell et al., 1976; Moyer, 1977; Randall, 2005b). None of these widespread damselfish species occur in the waters of the Marquesas Islands where L. bohar is abundant (Randall \& Earle, 2000, DelrieuTrottin et al., 2015). Hence, this study provides the first report of a case of mimicry by L. bohar of Chromis fatuhivae. The strategy to mimic an a priori rare species seems odd from an evolutionary point of view, but it seems probable that $C$. fatuhivae is actually 


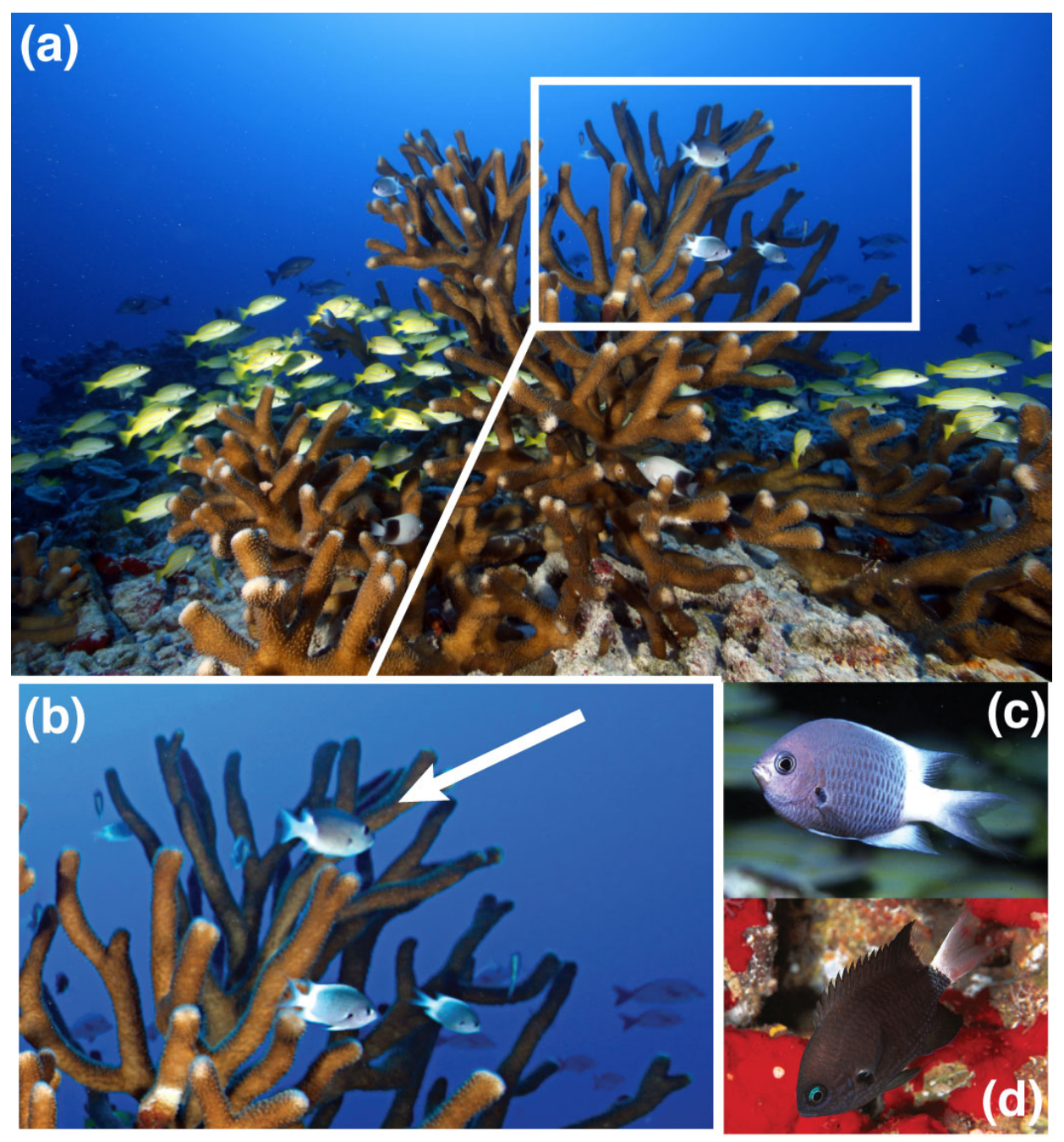

Figure 1: Banc Clark underwater landscape. (a) Coral head with the juvenile Lutjanus bohar [arrow in (b)]) mimic mingling with the endemic Chromis fatuhivae. (c) Chromis fatuhivae. (d) Chromis abrupta. Photographs credits: (a) and (b): Yann Hubert, (c): Luiz A. Rocha, (d) Philippe Bacchet. 
not rare in the Marquesas and its presumed rarity is a sampling artifact based on inadequate knowledge and limited sampling of its preferential habitat. In this study it was found not only at its type locality (Fatu-Hiva), but also to be common $500 \mathrm{~km}$ away at the submerged atoll Banc Clark, the northernmost point of the Marquesas Islands where the photograph was taken. Moreover, at Tuamotu Archipelago L. bohar is known to mimic C. margaritifer, a damselfish replaced in the Marquesas by its sister species $C$. abrupta Randall 2001 [Fig. 1 (d)] which is very abundant in Marquesan waters. Lutjanus bohar may also mimic this other white-tailed damselfish species in Marquesan waters.

All of the species that were collected during the census of the reef fish fauna were photographed to record fresh colour. By reviewing the photographic records for other potential mimetic associations involving endemic species, colour photographs were retrieved for a similar case in the Marquesas Islands, first reported by Randall (2005b) involving an endemic model with the cleaner wrasse mimic, the blenniid Aspidontus taeniatus Quoy \& Gaimard 1834. Throughout the Indo-Pacific, this blenny mimics Labroides dimidiatus (Valenciennes 1839) [Fig. 2 (a)] and uses mimicry to approach fishes and feed on pieces of fin or flesh from their potential clients instead of cleaning them (Russell et al., 1976; Kuwamura, 1983). In the Marquesas Islands, A. taeniatus can display two colour patterns, the classic colour pattern mimicking L. dimidiatus which is also present in the Marquesas Islands [Fig. 2 (a)] and another pattern mimicking the female of the Marquesan endemic wrasse, Coris hewetti Randall 1999 (Randall, 2005b) [Fig. 2 (b)]. In this latter pattern, the whitish areas become yellow posteriorly on the body and the caudal fin and the dark stripe on the anterior two-thirds of the body are flanked with a series of white dots along the upper margin, mimicking the female of the endemic wrasse, which is also involved in cleaning (Randall, 2005b).

The photographic records of this study also indicated previously unreported cases of endemic mimicry patterns, involving two other widespread species mimicking an endemic species and another possible endemic model species. Plagiotremus tapeinosoma (Bleeker 1857) usually mimics the initial phase of Thalassoma amblycephalum (Bleeker 1856) in the Pacific (Russell et al., 1976) [Fig. 2 (c)]; both species are present in the Marquesas Islands. In the current study it became apparent that $P$. tapeinosoma can also mimic C. hewetti in the Marquesas Islands [Fig. 2 (b)]. Moreover, Plagiotremus. rhinorhynchos (Bleeker 1852), known as opportunistically mimicking L. dimidiatus (Ct \& Cheney, 2005) may also mimic C. hewetti in the Marquesas Islands [Fig. 2 (b)]. The current study showed that the female of the endemic Marquesan wrasse, Stethojulis marquesensis Randall 2000, also displays a similar colour pattern to that of P. tapeinosoma, $P$. rhinorhynchos, $C$. hewetti and $A$. taeniatus; all forming a mimicry ring (i.e., mimetic 


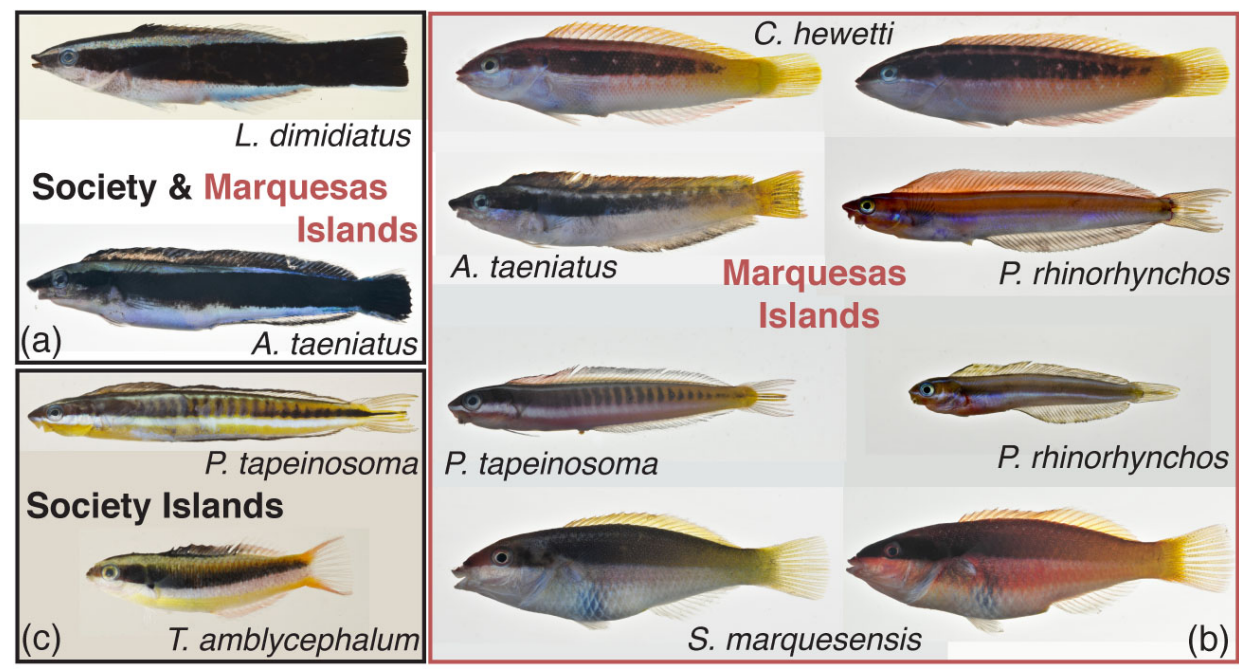

Figure 2: Mimics and their models. (a) Aspidontus taeniatus mimicking Labroides dimidiatus. (b) Mimicry ring involving the endemic Coris hewetti and Stethojulis marquesensis and their mimics: Aspidontus taeniatus, Plagiotremus rhinorhynchos and Plagiotremus tapeinosoma. (c) Plagiotremus tapeinosoma mimicking Thalassoma amblycephalum. 


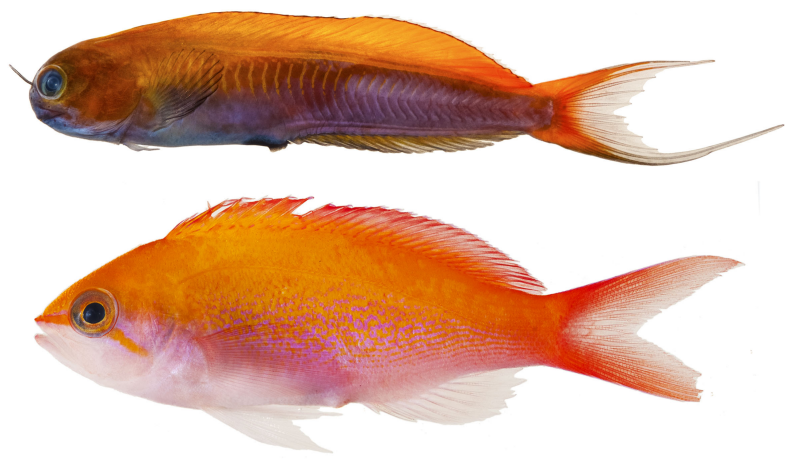

Figure 3: (b) Pseudanthias regalis and (a) its mimic Ecsenius midas.

relationships between multiple species). Because this complex mimicry case was only discovered from photographs rather than in-situ observations, the function of the complex is unknown. Stethojulis marquesensis may display this colour as a cleaning signal or for protective mimicry as cleaner species are less vulnerable to predation.

Finally, the blenniid Ecsenius midas Starck 1969 along with the damselfish Lepidozygus tapeinosoma (Bleeker 1856) are known to form feeding aggregations with and to mimic two anthiin species, Pseudanthias dispar (Herre 1955) and Pseudanthias bartlettorum (Randall \& Lubbock 1981) in the Line Islands and Phoenix Islands (Randall \& McCosker, 1993). Both are absent in the Marquesas Islands, and only the endemic Pseudanthias regalis (Randall \& Lubbock 1981) displays a similar colour pattern among the anthiin species present, characterized by the bright yellow above and bright pink below. In 2003, Luiz Rocha (pers. comm.) observed E. midas mimicking and schooling with the Marquesan endemic Pseudanthias regalis ; an illustration of that mimicry case is provided here (Fig. 3).

Mimicry is quite common in the marine environment and Randall reviews around a hundred cases (Randall, 2005b). However, the Marquesas seem to host an unusually high number of unique mimicry associations, involving endemic reef-fish species This discovery adds a new line of evidence to the uniqueness of the Marquesas Islands, which not only host a high number of endemic reef-fish species, but also endemic mimicry patterns that may be an engine for speciation processes.

The Pakaihi i te Moana expedition on board the R/V Braveheart was funded by the French Agence des Aires Marines Protegees and Fondation Total. We thank Y. Hubert, L. A. Rocha and P. Bacchet for sharing their underwater photographs. We thank L. A. Rocha 
for constructive comments on an earlier version of the manuscript.

\section{References}

Chevalier, J. (1978). Les coraux des iles Marquises. Cahiers du Pacifique 21, 243283.

Cote, I. M. \& Cheney, K. L. (2005). Animal mimicry: Choosing when to be a cleaner-fish mimic. Nature 433, 211-212.

Delrieu-Trottin, E., Williams, Bacchet, P., Kulbicki, M., Mourier, J., Galzin, R., Lison de

Loma, T., Mou-Tham, G., Siu, G. \& Planes, S. (2015). Shore fishes of the Marquesas Islands, an updated checklist with new records and percentage of endemic species. Check List 11, 1758.

Kuwamura, T. (1983). Reexamination on the aggressive mimicry of the cleaner wrasse Labroides dimidiatus by the blenny Aspidontus taeniatus (Pisces; Perciformes). Journal of Ethology 1, 2233.

Moyer, J. T. (1977). Aggressive mimicry between juveniles of snapper Lutjanus bohar and species of damselfish genus Chromis from Japan. Japanese Journal of Ichthyology 24, 218222.

Randall, J. E. (2001). Four New Damselfishes (Perciformes: Pomacentridae) from the Marquesas Islands. Copeia 2001, 92-107.

Randall, J.E. (2005a). Reef and Shore Fishes of the South Pacific. Sea Grant College Program, Honolulu, Hawaii: University of Hawaii Press.

Randall, J. E. (2005b). A Review of Mimicry in Marine Fishes. Zoological Studies 44, 299328.

Randall, J.E. \& Earle, J. L. (2000). Annotated Checklist of the Shore Fishes of the Marquesas Islands. Bishop Museum Occasional Papers 66, 142.

Randall, J. E., \& McCosker, J. E. (1993). Social mimicry in fishes. Revue Francaise d'Aquariologie 20, 58.

Russell, B. C., Allen, G. R. \& Lubbock H. R. (1976). New cases of mimicry in marine fishes. Journal of Zoology 180, 407423.doi: 10.1111/j.1469-7998.1976.tb04685.x

Wickler, W. (1965). Mimicry and the evolution of animal communication. Nature 208, 519521. doi:10.1038/208519a0 